\title{
Indigenous Peoples and Sustainable Development: A Monograph
}

\author{
Stanislav Gorbunov and Maksim Zadorin. Indigenous Peoples and Sustainable \\ Development: Monograph (Publishing house of the Northern (Arctic) Federal \\ University. Arkhangelsk. 2014). 358 pages. ISBN 978-5-261-00908-5.
}

Станислав Николаевич Горбунов и Максим Юрьевич Задорин. Коренные народы и устойчивое развитие: Монография (Издательский дом САФУ. Архангельск. 2014). 358 страниц. (Издательский дом САФУ. Архангельск. 2014). 358 страниц. (Издательский дом САФУ. Архангельск. 2014). 358 страниц. ISBN 978-5-26100908-5.

A highly topical issue, the problem of sustainable development has generated intense discussion in the academic community. Constituting up to five percent of the world's population, indigenous peoples represent one of the poorest and most disenfranchised segments of society. This isolates them from decision-making processes. Despite efforts to assimilate them, some indigenous peoples have succeeded in maintaining their indigenous knowledge and practices, which include valuable approaches to sustainable development.

Considering the world's sustainable development processes in terms of indigenous peoples' experiences is central for the authors of the book. The book deserves attention inasmuch as the issue of indigenous peoples' rights is underestimated in Russia, and very few legal scholars are conducting sufficient research in this field. The dearth of legal literature in the Russian language has created a gap in the understanding of indigenous rights' issues, actively discussed at the international level.

In their book, Gorbunov and Zadorin attempt to investigate both the culturalhistorical and the legal identity of the indigenous peoples of the world. In addition, the monograph analyses existing national legal concepts applicable to indigenous peoples struggling for their right to self-determination and sustainable development in the era of globalization.

The book consists of four chapters on the following: 
- prerequisites for the formation of indigenous peoples' legal status on national and international levels;

- indigenous peoples as bearers of the right to the environment;

- applicability of the international legal concept of self-determination to indigenous peoples;

- the primary areas of sustainable development of indigenous peoples.

The authors define the target audience as lawyers and legal specialists in constitutional law and international law.

The first chapter is devoted to the recognition processes of the status of indigenous peoples in international law. In addition, the authors view the status of indigenous peoples through analysis of national legal practices in the USA, Australia and New Zealand. The authors quote extensively from sources, refer to numerous historical examples and describe in detail the evolution of indigenous peoples' rights. However, Zadorin and Gorbunov do not provide an explanation for their choice of the three above-mentioned countries. Their choice is questionable because they are Russian researchers specializing in international and Russian law. It is not quite clear why these particular national practices are relevant for the focus chosen in the book.

The second chapter approaches the issue of the indigenous peoples' right to the environment. However, the authors do not define this right. Also, the authors present the idea of the interconnection of indigenous peoples' culture and their land rights as a self-evident fact. There is no convincing legal analysis to support the authors' position. Instead, the researchers philosophize and again refer to comprehensive historic examples. Presenting the issue in this context can be justified inasmuch as understanding indigenous rights requires a complex approach, however, the authors seem to fail to concentrate on the legal aspects of the issues and devote much room to non-legal ones. For example, the reference to Gumilyov's argument that defines ethnos as "a phenomenon of biosphere" is not relevant for research addressed to lawyers.

The third chapter addresses the issue of indigenous peoples' right to selfdetermination. This chapter has a logical structure. The authors' arguments lead to consequent conclusions. The analysis of the development of the recognition of the indigenous peoples' right to self-determination in international law is plausible. The chapter may be useful to Russian-speaking readers who are interested in the right to self-determination.

In the fourth chapter Gorbunov and Zadorin attempt to analyze aspects of sustainable development of indigenous peoples and make suggestions on how to improve the current situation in the sphere of indigenous peoples' rights and their sustainable development. Despite the fact that the entire book is devoted to the sustainable development of the indigenous peoples, the authors turn to this issue only in the fourth chapter. It is not clear to what extent the previous three chapters help to clarify the focus of the book. The authors suggest that more nations should ratify the Indigenous and Tribal Peoples Convention, 1989 (No. 169). They also insist that the United Nations Permanent Forum on Indigenous Issues should be 


\section{E. A. Zmyvalova}

granted the status of a specialized agency of the United Nations. Nonetheless, the authors do not specify how this special status can contribute to a more sustainable development of indigenous groups. The researchers also suggest strengthening the cooperation between indigenous communities and nations. While these suggestions seem reasonable, the authors do not propose any pioneering ideas that could be put into practice.

To conclude, it is difficult to evaluate whether the authors managed to achieve their research goal since no objective is stated in the book. Moreover, the absence of an outline in the text of the book makes it difficult to understand the relevance of certain portions. The authors' train of thought often lacks arguments and evidence to convince the critical reader. Nevertheless, the book is useful reading for Russian speakers who are interested in the history of indigenous peoples, indigenous practices, and the applicability of the sustainable development idea to a wider scope of issues. Despite its shortcomings, this book can facilitate a Russian audience's knowledge about indigenous peoples.

Ekaterina Andreyevna Zmyvalova, PhD student Humanisthuset, koridor HA1 Umeå Universitet 901 97, Umeå, Sweden. Email: ekaterina.zmyvalova@umu.se 